.

\title{
Long-term impact of acid resin waste deposits on soil quality of forest areas II.
} Biological indicators.

\section{Revised version 22.07.2008}
Alfredo Pérez-de-Mora ${ }^{\mathrm{a},{ }^{*}, \text { Engracia Madejón }}{ }^{\mathrm{b}}$, Francisco Cabrera ${ }^{\mathrm{b}}$, Franz Buegger ${ }^{\mathrm{a}}$, Roland $\mathrm{Fu}^{\mathrm{a}}$, Karin Pritsch ${ }^{\mathrm{a}}$, Michael Schloter ${ }^{\mathrm{a}}$

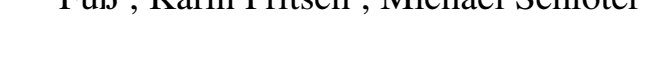



${ }^{\mathrm{a}}$ Helmholtz Zentrum München - Deutsches Forschungszentrum für Gesundheit und Umwelt

$(\mathrm{GmbH})$, Department of Terrestrial Ecogenetics, Institute of Soil Ecology,

Ingolstädterlandstrasse 1, 85764 Neuherberg, Germany.

Instituto de Recursos Naturales y Agrobiología de Sevilla (IRNAS-CSIC), Apartado 1052,

41080 Sevilla, Spain.

*corresponding author. Email address: perezdemora@ googlemail.com

telephone: 0049-89-3187-4539

19




\section{Abstract}

2 In this study, we evaluated the effects of two acid resin deposits on the soil microbiota of

3 forest areas by means of biomass, microbial activity-related estimations and simple biological

4 ratios. The determinations carried out included: total DNA yield, basal respiration,

5 intracellular enzyme activities (dehydrogenase and catalase) and extracellular enzyme

6 activities involved in the cycles of $\mathrm{C}$ ( $\beta$-glucosidase and chitinase), $\mathrm{N}$ (protease) and $\mathrm{P}$ (acid-

7 phosphatase). The calculated ratios were: total DNA/total N; basal respiration/total DNA;

8 dehydrogenase/total DNA and catalase/total DNA. Total DNA yield was used to estimate soil

9 microbial biomass. Results showed that microbial biomass and activity were severely

10 inhibited in the deposits, whilst resin effects on contaminated zones were variable and site-

11 dependant. Correlation analysis showed no clear effect of contaminants on biomass and

12 activities outside the deposits, but a strong interdependence with natural organic matter

13 related parameters such as total $\mathrm{N}$. In contrast, by using simple ratios we could detect more

14 stressful conditions in terms of organic matter turnover and basal metabolism in contaminated

15 areas compared to their uncontaminated counterparts. These results stress that developed

16 ecosystems such as forests can buffer the effects of pollutants and preserve high functionality

17 via natural attenuation mechanisms, but also that acid resins can be toxic to biological targets

18 negatively affecting soil dynamics. Acid resin deposits can therefore act as contaminant

19 sources adversely altering soil processes and reducing the environmental quality of affected

20 areas despite the solid nature of these wastes.

22 Keywords: acid resin; enzyme activities; heavy metals; hydrocarbons; trace elements; total 23 DNA 


\section{1. Introduction}

Anthropogenic activities can disturb normal soil functioning and have deleterious

3 effects on environmental quality. Physical and chemical soil properties such as texture,

4 aggregate structure, $\mathrm{pH}$, organic matter content, etc., are all involved in the behaviour of soils

5 and their response to external changes (Parr et al., 1992). However, biochemical and

6 microbiological properties such as enzyme activities, microbial biomass and respiration have

7 been outlined as particularly appropriate for evaluation of soil quality (Pankhurst et al., 1995),

8 due to the key role of microorganisms in the cycling of nutrients, the metabolic capacity and

9 the functional integrity of soils (Nannipieri et al., 2003).

Various studies have shown that inorganic and organic contaminants can have

11 negative effects on soil microbial properties (Benítez et al., 2004; Pérez-de-Mora et al 2005,

12 2006; Dawson et al., 2007). Heavy metals are known to cause long-term toxic effects within

13 ecosystems and can have a negative influence on soil biological processes (Lee et al., 2002;

14 Kizilkaya et al., 2004). They can also affect microbial proliferation and enzyme activities by

15 masking catalytically active groups, altering protein conformation or competing with other

16 metals involved in the formation of enzyme-substrate complexes (Eivazi and Tabatabai,

17 1990). However, long-term exposure to heavy metals may also enhance microbial tolerance in

18 soil (Baath et al., 1998; Del Val et al., 1999). In this case, no net effect on broad microbial

19 indices such as soil respiration or microbial biomass may be observed (Khan and Scullion,

20 2000).

Hydrocarbons can exert a negative impact on soil quality and soil biology. Short nalkanes can act as solvents for cellular fats and membranes (Sikkema et al., 1995), whereas

23 long chain n-alkanes may contribute to the formation of oil films and slicks, which may in

24 turn block the exchange of water, nutrients and gases (Leahy and Colwell, 1990). Polycyclic

25 aromatic hydrocarbons are known to be carcinogenic, teratogenic and mutagenetic (Miller and 
1 Ramos, 2001) and negative effects on the soil microbiota have been also reported (Dechsel et

2 al., 1996; Smreczek et al., 1999). On the other hand, specialized microorganisms can use

3 hydrocarbons as energy and $\mathrm{C}$ source and thus proliferate on sites contaminated with such

4 compounds (Coulon et al., 2007; Wentzel et al., 2007).

5 Numerous investigations have assessed the effects of particular contaminants or specific

6 groups of contaminants on soil biochemical and biological properties in agricultural 7 ecosystems. However, there are few studies of interactions between microbiological 8 properties and complex contaminations in forest ecosystems, which still dominate the

9 landscape of many areas in Europe. Knowledge of such interactions and their consequences in

10 the long-term are important to the ecotoxicological assessment of contaminated soils. In this

11 work, we studied various microbiological and biochemical properties and calculated simple

12 ratios to evaluate the effects of acid resin wastes on soil functionality and overall microbial

13 activity in affected areas. General chemical and contaminant data presented in Pérez-de-Mora

14 et al. (in press) was used to interpret activity patterns in soil.

\section{Material and methods}

17 A description of the sites (Schlangenburg = site A and Seelacher Berg $=$ site B), the 18 sampling and the general chemical properties, hydrocarbon and trace element concentrations 19 of the soils can be found in Pérez-de-Mora et al. (in press).

\subsection{Total DNA yield}

Samples for total nucleic acid extraction were kept in dry ice until stored at $-80^{\circ} \mathrm{C}$.

23 Total nucleic acids from soil $(0.5 \mathrm{~g} \mathrm{dw})$ were extracted using the method of Griffiths et al.

24 (2000). Cells were lysed via mechanical shaking in Precellys-Keramik-Kit Tubes (PeqLab, 
1 Erlangen, Germany) with a Precellys $24{ }^{\circledR}$ Lysis and Homogenisation Automated Equipment

2 (Bertin technologies, France). Extracted nucleic acids were resuspended in 50mL miliQ water

$3(\mathrm{pH}=6.8)$ and concentration of total DNA was measured via a Nanodrop ${ }^{\circledR}$ ND-1000

4 spectrometer (Nanodrop Technologies, Wilmington, DE ,US) at 260nm. Extractions were

5 carried out in duplicate. The quality of the DNA extracted was checked by comparing the

6 ratios OD 260/280 and OD 260/230 between samples. Control and contaminated samples did

7 not differ in this regard. Additionally, viability of DNA was examined via PCR amplification

8 of $16 \mathrm{~S} r R N A$ and $18 \mathrm{~S}$ rRNA fragments.

\subsection{Soil basal respiration}

Soil samples (3-5g and 60\% WHC) were incubated up to three days at $25^{\circ} \mathrm{C}$ in closed

12 glass jars $\left(120 \mathrm{~mL}\right.$ ) (Isermeyer, 1952). Concentrations of $\mathrm{CO}_{2}$ produced were determined

13 using a Gas Chromatograph (GC-14B, Shimadzu Corporation, Kyoto, Japan) equipped with

14 an Electron Capturer Detector $\left(280^{\circ} \mathrm{C}\right)$. Separation of $\mathrm{CO}_{2}$ from other gases in the sample was

15 achieved through a Porapack Q column (80-100 $\mu$ m Mesh, Millipore). Column temperature

16 was $60^{\circ} \mathrm{C}$ and the carrier gas was nitrogen (ECD quality, Linde); a flow of $20 \mathrm{~mL} \mathrm{~min}^{-1}$ was

17 used.

\subsection{Soil enzyme activities}

Dehydrogenase activitity was estimated after incubating soil samples with $0.5 \% 2-p$ iodophenyl 3-p-nitrophenyl-5 tetrazolium chloride (INT) solution and determination of the reduced product iodonitrotrezolium formazan (INTF) via a colorimetric assay at 490nm (Cary

23 Elipse UV/visible Spectrophotometer, Varian, Australia) (von Mersi and Shinner, 1991). 
1 estimation of the remaining $\mathrm{H}_{2} \mathrm{O}_{2}$ via colorimetric determination $(\lambda=505 \mathrm{~nm})$ (Trasar-Cepeda

2 et al., 1999).

3 Protease activity was estimated by quantifying colorimetrically $(\lambda=700 \mathrm{~nm})$ the release

4 of aromatic amino acids after incubation of soil samples with a buffered casein solution (Ladd

5 and Butler, 1972).

6 The activities of acid-phosphatase, $\beta$-d-glucosidase and chitinase were measured using 7 a microplate fluorometric assay (Marx et al., 2001). Soil suspensions were incubated with the 8 appropriate substrate at $\mathrm{pH}=6(800 \mu \mathrm{M}$ of $4-\mathrm{MUB}$-phosphate for $20 \mathrm{~min} ; 400 \mu \mathrm{M} 4-\mathrm{MUB}-\beta$-D9 glucoside for $40 \mathrm{~min}$ and $400 \mu \mathrm{M}$ 4-MUB-N-acetyl- $\beta$-D-glucosaminide for 40min). 10 Determination of the 4-methyl umbelliferone (4-MUB) released after the incubation was 11 carried out with a fluorescence spectrophotometer (Cary Elipse Fluorescence 12 Spectrophotometer, Varian, Australia) at an excitation wavelength of $340 \mathrm{~nm}$ and emission at $13450 \mathrm{~nm}$. Controls with water or substrate instead of soil suspension were also performed. A 14 calibration curve for each zone was prepared to minimize the quenching effect due to 15 differences in organic matter quality and quantity of soil samples.

\subsection{Statistical analysis}

18 Univariate statistical analyses were performed using the program SPPS 15.0 for 19 Windows. A normality test was carried out for all variables prior to analysis of the variance.

20 The chemical and microbiological data was analysed by ANOVA, considering the sampling 21 zone as the independent variable. Significant statistical differences of all variables between 22 the different zones were established by Tukey's test when there was homogeneity of the 23 variance and by Games-Howell's test in the opposite case. Correlation matrixes for each site 24 between microbiological properties and biochemical and chemical properties were also 25 calculated. The significance level reported $(\alpha=0.01$ and $\alpha=0.05)$ is based on Pearson`s 
1 coefficients. Correlations were performed separately for each site as combining the two

2 datasets changed some of the local interdependencies. In order to evaluate the effects of

3 contaminants on biological properties in the surroundings, deposits were excluded from the

4 correlation analysis, as results from ANOVA analysis clearly showed that biological activity

5 was severely reduced in the latter area.

6

7 3. Results

8 3.1. Total DNA

9 Total DNA yield in samples from the deposits were extremely poor $\left(0.4 \mu \mathrm{g}\right.$ DNA g $\left.{ }^{-1}\right)$ and 10 this material could not be amplified via PCR. In the surroundings, DNA concentrations were

11 significantly higher and $16 \mathrm{~S} r R N A$ and $18 \mathrm{~S} r R N A$ amplicons could be obtained from all 12 samples, independently from the degree of contamination. In site A, DNA yields were about

1310 times higher in control than in contaminated zones, whereas no significant differences 14 were found in site B (Figure 1a).

\section{3.2. Basal respiration}

17 Basal respiration in the deposits was either not detectable or extremely low in comparison 18 with contaminated and control areas (Figure 1b). In surrounding zones of site A, respiration 19 rate was found to be markedly higher in control (1.8-6 times) than in contaminated areas 20 (Figure 1b). In the latter, significant differences were also reported between zones $\mathrm{X}_{\mathrm{A} 1}$ and $21 \mathrm{X}_{\mathrm{A} 3}$ (Figure 1b). A different situation was observed in site $\mathrm{B}$, where contaminated zones 22 showed larger $\mathrm{C}-\mathrm{CO}_{2}$ production than the control area (approx. 10 times) (Figure 1b). 23 Significant differences were also reported between $X_{B 1}$ and the other contaminated zones 24 (Figure 1b). 


\subsection{Intracellular enzyme activities}

In site A, dehydrogenase activity in the control zone was 5 fold higher than in contaminated zones and about 14 fold larger than in the deposits (Figure 1c). In site B, similar results were obtained in control and contaminated areas and mean values in these areas were around 15 fold larger than those found in the deposit (Figure 1c).

Catalase activity in site A was found to be 3-6 times higher in the control than in the other areas, but there were no differences between the deposit and contaminated zones (Figure 1d). In site B, there were no significant differences between control and contaminated zones, but catalase activity in these areas was substantially higher than in the deposits (Figure 1d).

\subsection{Extracellular enzyme activities}

In general, potential extracellular activities followed a similar trend to intracellular enzymes with higher activity values outside than inside the deposits, where some enzymes were even inhibited (Figure 2). As a rule higher activity patterns were observed in control than in contaminated zones of site A, whilst similar or even higher enzymatic values were recorded in contaminated zones of site B compared with the control area (Figure 2).

No $\beta$-glucosidase activity was detected in the deposits. In site A, mean activity was between 2.5-10 fold higher in the control than in contaminated zones (Figure 2a). The lowest activity values were recorded in zone $\mathrm{X}_{\mathrm{A} 2}$ (Figure 2a). By contrast, enzymatic activity in contaminated zones of site B was about 10 fold larger than that in the control area (Figure 2a). No activity differences were recorded among contaminated zones in site B.

In contrast to $\beta$-glucosidase, chitinase activity was not inhibited in the deposits (Figure 2b). Nonetheless, the lowest activity values in both sites were recorded here. In site A, chitinase activity was highest in the control area, but differences with contaminated zones were not as inherent as for $\beta$-glucosidase (Figure $2 b$ ). In site $B$, chitinase activity in 
1 contaminated zones was 2-4 times higher than in the control (Figure 2b). The highest values

2 were recorded in zone $\mathrm{X}_{\mathrm{B} 1}$.

3 There was no protease activity in deposit A and mean values in deposit B were extremely

4 low (Figure 2c). In site A, protease activity in control was 4-38 fold higher than that in

5 contaminated zones (Figure 2c). There were also significant differences among contaminated

6 zones: potential activity in $\mathrm{X}_{\mathrm{A} 1}$ was more than twice than in the remaining zones (Figure $2 \mathrm{c}$ ).

7 In site B, however, there were no significant differences between control and contaminated

8 zones (Figure 2c). Here, protease activity was more than 30 fold larger than in the deposit.

9 No acid-phosphatase activity was recorded in deposit B, while in deposit A, although low,

10 enzymatic activity was similar to some of the contaminated zones (Figure 2d). In site A, the

11 highest activity was recorded in the control area. Here, potential activity was $2.5-7$ fold higher

12 than in contaminated zones (Figure 2d). In contrast, in site B enzymatic response was larger

13 in contaminated areas than in the control (Figure 2d), but no significant differences between

14 contaminated zones were observed.

\section{3.5. Microbiological ratios}

17 The total DNA/total $\mathrm{N}$ ratio showed inherent differences between control, deposit and 18 contaminated zones in the following order: deposit $<$ contaminated $<$ control (Figure $3 a$ ).

19 Although there were no significant differences between contaminated zones in none of the 20 sites, an increasing trend was observed from more contaminated to less contaminated zones in 21 site B (Figure 3a).

22 Ratios related to respiration/total DNA, including those based on intracellular enzymes, 23 were generally highest in the deposits followed by contaminated zones (Figures $3 b, c$ and d).

24 As a rule there were significant differences between controls, deposits and contaminated 25 zones, but not among contaminated zones in the same site, except in the case of zone $\mathrm{X}_{\mathrm{B} 3}$, 
1 where lower ratios were observed compared to the other contaminated areas (Figures $3 \mathrm{~b}, \mathrm{c}$

2 and d).

4 4. Discussion

$5 \quad$ 4.1. Total DNA yield

6 The soil microbial biomass plays a decisive role in the cycling of nutrients, the degradation

7 of organic compounds and other xenobiotics, and the immobilisation/release of trace elements

8 (Nannipieri et al., 2002). Commonly, microbial biomass in soil is estimated by the chloroform

9 fumigation-extraction method (Vance et al., 1987). However, as we determined the $C_{\text {mic }}$ and

$10 \mathrm{~N}_{\text {mic }}$ contents of soil samples by this procedure abnormally elevated $\mathrm{C}_{\text {mic }} / \mathrm{N}_{\text {mic }}$ ratios (above

11 20) were found in contaminated areas and the deposits (data not shown). Since soil

12 microorganisms have typical ratios of $5-10$, this bias seemed to be caused by the dissolution

13 of hydrocarbons in chloroform. To have an estimation of the soil microbial biomass, we

14 employed a well-known DNA extraction procedure (Griffiths et al., 2000). This approach is

15 less time consuming than microscopic counting of microorganisms and gives an overall

16 estimation of microbial biomass (bacteria, fungi and archaea). Although plant and animal

17 material may be co-extracted, the highly positive correlations between total DNA yield and

18 respiration and enzyme activities in both sites support the utilization of this approach in our

19 study (all above $0.600 \mathrm{p}<0.01$; data not shown). Despite a period of 60 years since dumping

20 of the waste, extraordinary low values of total DNA were found in the two deposits. Here,

21 microbial colonization was likely to be limited by the extreme nature of the resin (acid,

22 hydrophobic and enriched with contaminants). Outside the deposits, DNA yields differed

23 between control and contaminated zones in site A, but not in site B. These results could be

24 highly influenced by differences in natural organic matter between control and contaminated

25 zones of site A, in contrast to their respective counterparts in site B. This hypothesis is based

26 on the positive correlation between total DNA and total $\mathrm{N}$ (Tables 1 and 2), which can be 
1 considered more indicative of the natural organic matter content in our soils than total organic

$2 \mathrm{C}$, since $\mathrm{N}$ was not a major component of the resin (Pérez-de-Mora et al., in press). The

3 higher clay content of soil B could also account for higher DNA yields in contaminated zones

4 of site B compared to those of site A, since microorganisms are mainly associated with the

5 finer soil fractions (Kandeler et al., 2000). It should be noted that proliferation of hydrocarbon

6 degrading communities or metal resistant populations in contaminated zones of site B could

7 also contribute to higher biomass and hence DNA yields. Results also suggest that there was

8 no clear effect of contaminants on biomass outside the deposits. At least, no strong negative

9 correlations were reported (Tables 1 and 2). Furthermore, no patent effect of soil $\mathrm{pH}$ was

10 observed on DNA yields in site A in spite of the acidity of the resin (Table 1). It is possible,

11 however, that less acidic conditions in some contaminated parts of site B, could have

12 stimulated microbial development. The buffering capacity of the soil (naturally acid) was

13 apparently sufficient to attenuate the acidity of the resin quite effectively or else the acidity

14 generated by the resin was no greater than that of the soil.

\section{4.2. Soil basal respiration and enzyme activities}

17 The basal respiration rate can reflect both the rate of mineralization of soil organic $\mathrm{C}$ and 18 the activity of microorganisms (Giller et al., 1998). The lack or remarkably low respiration

19 rate of the deposits stresses the severity of the resin as a habitat for microorganisms. The fact

20 that some respiration was measured in deposit B (Figure 1b), suggests that some acidophilic

21 microorganisms may be present here. Further studies should be carried out to find out why

22 this did not happen in deposit A. Outside the deposits respiration rate was apparently

23 influenced by other variables such as microbial biomass rather than by contaminant

24 concentrations (Table 2). Such differences can be interpreted better when normalizing

25 respiration rates through microbial biomass yields. This is further discussed in subsection 4.3. 
Soil enzymes are considered to be sensitive indicators of contamination because of their

2 role in organic matter cycling and regulation of nutrient pools (Visser and Parkinson, 1992).

3 For this reason, we evaluated two intracellular enzymes such as dehydrogenase and catalase,

4 which typically reflect general microbial activity in soil (García et al., 1997; Carmiña et al.,

5 1998), and various extracellular enzymes involved in the cycling of $\mathrm{C}$ ( $\beta$-glucosidase and

6 chitinase), $\mathrm{N}$ (protease) and $\mathrm{P}$ (acid-phosphatase). Results from enzymatic tests were quite

7 consistent with those of total DNA and basal respiration, showing that the resin had a clear

8 negative effect on these properties in the deposits, but not in the surroundings. Here, the soil

9 enzymatic response was more likely influenced by the amount of microbial biomass (total

10 DNA) and natural organic matter (total $\mathrm{N}$ ) rather than the degree of contamination. This is

11 supported by the strong positive correlations between microbiological properties and total $\mathrm{N}$,

12 including enzymatic activities of the $\mathrm{C}$ and $\mathrm{P}$ cycles, and the lack of high negative correlations

13 with contaminants in both sites (Tables 1 and 2). This would explain for instance why in

14 contaminated zones of site B similar or even higher intra- and extra-cellular enzyme activities

15 were recorded compared to the control. Soil organic matter plays a dual role as a source for

16 enzyme production and energy reservoir and can therefore promote microbial activity and

17 development. Furthermore, the higher natural organic matter and clay content of contaminated

18 zones of site B compared to those of site A, could also enhance adsorption of extra-cellular

19 enzymes with inorganic complexes or those associated with organic colloids. Such complexes

20 are characterised by a marked resistance to thermal and proteolytic degradation and allows

21 activities to persist in harsh conditions inhibiting microbial activity (Nannipieri et al., 2002).

22 In addition, less acidic conditions in contaminated zones of part B, could also account for

23 high enzymatic activity in this zone, since soil $\mathrm{pH}$ is crucial for enzymatic survival and

24 functioning (Acosta-Martínez and Tabatabai, 2000). 
The potential of absolute enzyme activities to respond to environmental stress such as

2 pollutants has been questioned (Trasar-Cepeda et al., 2000). In agreement with this, we did

3 not find a consistent response of biochemical properties to contaminant concentrations outside

4 the deposits. Several authors have proposed that the limitations of individual biochemical

5 properties may be overcome by using simple indicators such as the ratio between two

6 biochemical properties (Aoyama and Naguno, 1997; Dalal, 1998).

7 One of these indices is the microbial biomass/total organic $\mathrm{C}$ ratio, which has been 8 proposed as a useful indicator of soil pollution by heavy metals (Brookes, 1995) and organic 9 matter turnover (Insam and Mershack, 1997). Due to the interferences observed with these 10 two properties, we calculated an alternative ratio based on total DNA yields and total $\mathrm{N}$ 11 estimations. As it is depicted in Figure 3a, higher ratios were observed in controls than in 12 contaminated zones and, in turn, in contaminated zones than in the deposits. A higher ratio 13 indicates that soil microorganisms can use organic matter more efficiently and thus 14 environmental conditions are less stressful for microbial development (Spargling, 1992).

15 Although the ratio was not able to discriminate significantly between different pollution levels 16 in contaminated areas, negative correlations were observed for most contaminants, 17 particularly in site B (Table 2). Here, the ratio augmented as distance from the deposit 18 increased (Figure 3a).

19 Another simple indicator commonly used to evaluate microbial stress and soil disturbance

20 is the basal respiration/soil microbial biomass ratio $\left(\mathrm{qCO}_{2}\right)$ (Insam and Domsch, 1988;

21 Anderson and Domsch, 1993). The ratio is generally higher in distorted systems compared to

22 stable systems, since survival under stress conditions requires additional energy, which cannot 23 be utilized for growth (Haynes, 1999). As we did for biomass/total organic C, we calculated 24 an alternative ratio based on basal respiration and total DNA yields. The ratio was 25 significantly higher in all contaminated areas than in controls and correlated positively with 26 many of the contaminants in both sites (Tables 1 and 2). Although no consistent response was 
1 observed for deposit B in relation to affected zones, significant differences were observed

2 between contaminated zones in both sites, with higher ratios in areas closer to the deposits

3 (Figure 3b).

4 Enzyme/total DNA ratios were also calculated for intracellular and extracellular enzymes,

5 but only those of intracellular activities (dehydrogenase and catalase) showed a consistent

6 response in both sites (Figures $3 \mathrm{c}$ and d). This may be attributed to the fact that intracellular

7 enzymes are closely related to microbial activity and respiration in contrast to extracellular

8 enzymes, whose activity is usually independent from the state of the organism (active,

9 inactive or dead) that produces it (Nannipieri et al., 2002). Both ratios decreased significantly

10 following the order deposit $>$ contaminated zones $>$ control. For site B, both ratios were

11 significantly lower in $\mathrm{X}_{\mathrm{B} 3}$ than in other contaminated zones and similar to those found in

12 control (Figures $3 c$ and d).

13 Some authors have proposed the use of complex indicators involving various biochemical 14 properties to estimate changes in soil quality (Beck, 1984; Stefanic, 1994; Trasar-Cepeda et 15 al., 2000). However, there is no consensus at present among soil scientists about a universal 16 indicator that may be used in all situations, probably because of the complexity of many soils, 17 particularly of multi-element contaminated sites, where many biotic and abiotic factors 18 interact. As proposed by Nannipieri et al., (2002) we tried to assess changes in soil quality by 19 means of various microbiological and biochemical properties and the utilization of simple 20 ratios. With this approach we could show that: a) acid resins are toxic wastes for soil 21 microorganisms, b) there is a higher stress for microbial populations in contaminated areas 22 compared to controls, and c) outside the deposits, soil functional diversity seems to be more 23 related to biological and abiotic properties such as microbial biomass and total $\mathrm{N}$ content 24 rather than to contaminant concentrations. 
1 Acid resin deposits are extreme habitats offering little chances for microbial colonization. The

2 contamination of surrounding areas as a result of contaminant release and transport of acid

3 resin fragments had a negative effect on soil microbial populations, decreasing organic matter

4 turnover and metabolic efficiency. Nonetheless, the natural attenuation potential of developed

5 systems such as forests, as reflected by its natural organic matter and other soil constituents,

6 can buffer the toxicity of such wastes maintaining soil functionality even at extreme levels of

7 contamination. Given the toxicity of such wastes and the degree of contamination of

8 surrounding areas, deposits should be ideally isolated or removed to prevent further

9 deterioration of these sites, as long as it is technically possible. Depending on end-use

10 strategies and transport of contaminants to groundwater, natural attenuation mechanisms may

11 be an economic and feasible option for affected zones.

\section{Aknowledgements}

14 Dr. Pérez-de-Mora thanks the Spanish Ministry of Education and Science (MEC) for the 15 fellowship. Special thanks to Hufnagel, G. and Schilling, R. for technical assistance in various 16 determinations. The authors also want to thank the anonymous reviewers of STOTEN for 17 their helpful comments to improve the manuscript.

19 Literature

20 Acosta-Martínez V, Tabatabai MA, Enzyme activities in a limed agricultural soil. Biol Fertil 21 Soils 2000; 31: 85-91.

22 Anderson T, Domsch $\mathrm{KH}$. The metabolic quotient for $\mathrm{CO}_{2}\left(\mathrm{qCO}_{2}\right)$ as a specific activity 23 parameter to assess the effects of environmental conditions, such as $\mathrm{pH}$, on the microbial 24 biomass of the soil. Soil Biol Biochem 1993; 25: 393-395. apple orchard soils on microbial activities. Soil Sci Plant Nutr 1996; 43: 601-612. 
1 Bååth E, Díaz-Raviña $\mathrm{M}$, Frostegård $\mathrm{A}$, Campbell $\mathrm{CD}$. Effect of metal-rich sludge amendments on the soil microbial community. Appl Environ Microbiol 1998; 64: 238245.

4 Beck T. Methods and application of soil microbiological analysis at the Landensanstalt für

5 Bodenkultur und Pflanzenbau (LBB) in Munich for the determination of some aspects of soil

6 fertility. In: Nemes MP, Kiss S, Papacostea P, Stefanic C, Rusan M, editors. Research

7 Concerning a Biological Index of Soil Fertility. Fifth Symposium on Soil Biology, Romanian

8 National Society of Soil Science, Bucharest, 1984, 13-20.

9 Benítez E, Melgar R, Nogales R. Estimating soil resilience to a toxic organic waste by

10 measuring enzyme activities. Soil Biol Biochem 2004; 36: 1615-1623.

11 Brookes PC. The use of microbial parameters in monitoring soil pollution by heavy metals.

12 Biol Fert Soils 1995; 19: 269-279.

13 Carmiña F, Trasar-Cepeda C, Gil-Sotrés F, Leirós MC. Measurement of dehydrogenase

14 activity in acid soils rich in organic matter. Soil Biol Biochem 1998; 30: 1005-1011.

15 Coulon F, McKew BA, Osborn AM, McGenity TJ, Timmis KN. Effects of temperature and

16 biostimulation on oil-degrading microbial communities in temperate

17 estuarine waters. Environ Microbiol 2007; 9(1): 177-186.

18 Dalal RC. Soil microbial biomass—what do the numbers really mean? Aust J Exp Agr 1998;

19 38: 649-665.

20 Dawson JJC, Godsiffe EJ, Thompson IP, Ralebitso-Senior TK, Killham KS, Paton GI.

21 Application of biological indicators to assess recovery of hydrocarbon impacted soils. Soil

22 Biol Biochem 2007; 39: 164-177.

23 Delschen T, Hembrock-Heger A, Necker U. Das Verhalten von 14C Fluor(a)anthen und

24 Benzo(a)pyren sowie 14C-PCB 28 und -PCB 52 in Agrarökosystem-Lysimeter-Versuche

25 mit einer Parabraunerde aus Löss. In Landesumweltamt NRW (Hrsg.): Materialien zur

26 Ermittlung und Sanierung von Altlasten, 1996, Bd.13. 
1 Del Val C, Barea JM, Azcón-Aguilar C. Assessing the tolerance to heavy metals of arbuscular mycorrhizal fungi isolated from sewage sludge contaminated soils. App Soil Ecol 1999; 11: 261-269.

Eivazi F, Tabatabai MA. Factors affecting glucosidase and galactosidase activities in soil. Soil Biol Biochem 1990; 22: 891-897.

García C, Roldán A, Costa F. Potential use of dehydrogenase activity as an index of microbial activity in degraded soils. Commun Soil Sci Plan 1997; 12: 123-34.

Giller KE, Witter E, McGrath SP. Toxicity of heavy metals to microorganisms and microbial processes in agricultural soils: a review. Soil Biol Biochem 1998; 30: 1389-1414.

Gil-Sostrés F, Trasar-Cepeda C, Leirós MC, Seoane S. Different approaches to evaluating soil quality using biochemical properties. Soil Biol Biochem 2005; 37: 877-887.

Griffiths RI, Whiteley A, O'donnell AG, Bailey MJ. Rapid method for coextraction of DNA and RNA from natural environments for analysis of ribosomal DNA and rRNA-based microbial community composition. Appl Environ Microb 2000; 66: 5488-5491.

Haynes RJ. Size and activity of the soil microbial biomass under grass and arable management. Biol Fert Soils 1999; 30: 210-216.

Insam H, Domsch KH. Relationship between soil organic carbon and microbial biomass on chronosequences of reclamation sites. Microbiol Ecol 1998; 15: 177-188.

Insam H, Merschack P. Nitrogen leaching from forest soil cores after amending organic recycling products and fertilizers. Waste Manage Res 1997; 15: 277-292.

Isermeyer H. Eine einfache Methode zur Bestimmung der Boden Atmung und der Karbonat im Boden. Zetischrift für Pflanzernährung und Bodenkunde 1952; 56: 26-38.

Kahn M, Scullion J. Effect of soil on microbial responses to metal contamination. Environ Pollut 2001; 110: 115-125. 
1 Kandeler E, Tscherko D, Bruce KD, Stemmer M.Hobbs PJ, Bardgett RD, Amelung W.

2 Structure and function of the soil microbial community in microhabitats of a heavy metal

3 polluted soil. Biol Fertil Soils 2000; 32: 390-400.

4 Kizilkaya R, Aşkin T, Bayrakli B, Sağlam M. Microbial characteristics of soils contaminated

$5 \quad$ with heavy metals. Eur J Soil Biol 2004; 40: 95-102.

6 Ladd JN, Butler JHA. Short-term assays of soil proteolytic enzyme activities using proteins

$7 \quad$ and dipeptide derivatives as substrates. Soil Biol Biochem 1972; 4: 19-30.

8 Leahy JG, Colwell RR. Microbial degradation of hydrocarbons in the environment. Microb

$9 \quad \operatorname{Rev} 1990 ; 54: 305-315$.

10 Lee I-S, Kim OK, Chang Y-Y, Bae B, Kim HH, Baek KH. Heavy metal concentrations and

11 enzyme activities in soil from a contaminated Korean shooting range. J Biosci Bioeng

$12 \quad 2002 ; 94: 406-411$.

13 Marx MC, Wood M, Jarvis SC. A microplate fluorimetric assay for the study of enzyme

14 diversity in soils. Soil Biol Biochem 2001; 33: 1633-1640.

15 Miller KP, Ramos KS. Impact on cellular metabolism on the biological effects of

16 benzopyrene and related hydrocarbons. Drug Metab Rev 2001; 33: 1-35.

17 Nannipieri P, Kandeler E, Ruggiero P. Enzyme activities and microbiological and

18 biochemical processes in soil. In: Burns RG, Dick RP, editors. Enzymes in the

19 Environment. Marcel Dekker, New York, 2002; 1-34.

20 Nannipieri P, Ascher J, Ceccherini MT, Loretta L, Giacomo P, Giancarlo R. Microbial

21 diversity and soil functions. Eur J Soil Sci 2003; 54: 655-670.

22 Parr JF, Papendick RI, Hornick SB, Meyer RE. Soil quality: attributes and relationship to

23 alternative and sustainable agriculture. Am J Alternative Agri 1992; 7: 5-11.

24 Pankhurst CE, Hawke BG, McDonald HJ, Kirkby CA, Buckerfield JC, Michelsen P, O'Brien

25 KA, Gupta VVSR, Doube BM. Evaluation of soil biological properties as potential

26 bioindicators of soil health. Aust J Exp Agr 1995; 35: 1015-1028. 
1 Pérez de Mora A, Ortega-Calvo JJ, Cabrera F, Madejón E. Changes in enzyme activities and microbial biomass after "in situ" remediation of a heavy metal-contaminated soil. Appl Soil Ecol 2005; 28: 125-137.

Pérez de Mora A, Burgos P, Madejón E, Cabrera F, Jaeckel P, Schloter M. Microbial community structure and function in a soil contaminated by heavy metals: effects of plant growth and different amendments. Soil Biol Biochem 2006; 38: 327-341.

Pérez-de-Mora A, Madejón E, Cabrera F, Buegger F, Fuß R, Pritsch K, Schloter M Long-term impact of acid resin waste deposits on soil quality of forest areas I. Contaminants and abiotic properties. Sci Total Environ (in press).

Sikkema J, de Bondt JAM, Pooman B. Mechanisms of membrane toxicity of hydrocarbons. Microbiol Rev 1995; 59: 201-222.

Smreczek B, Maliszewska-Kordybuch B, Martyniuk S. Effect of PAHs and heavy metals on activity of soil microflora. In: Baveye P, Block J-C, Goncharuk VV, editors. Bioavailability Of Organic Xenobiotics in the Environment. Dodreacht Hordbomd, Kluwer Academic Publishing, 1999; 377-380.

Spargling GP. Ratio of microbial biomass carbon to soil organic carbon as sensitive indicator of changes in soil organic matter. Aust J Soil Res 1992; 39: 195-207.

Stefanic G. Biological definition, quantifying method and agricultural interpretation of soil fertility. Romanian Agricult Res 1994; 2: 107-116.

Trasar-Cepeda C, Carmiña F, Leirós MC, Gil-Sotrés F. An improved method to measure catalase activity in soils. Soil Biol Biochem 1999; 31: 483-485.

Trasar-Cepeda C, Leirós MC, Seoane S, Gil-Sotrés F. Limitations of soil enzymes as indicators of soil pollution. Soil Biol Biochem 2000; 32: 1867- 1875.

Vance ED, Brookes PC, Jenkinson DS. An extraction method for measuring soil microbial biomass C. Soil Biol Biochem 1987; 19: 689-696. 
1 Visser S, Parkinson D. Soil biological criteria as indicators of soil quality: soil

2 microorganisms. Am J Altern Agr 1992; 7: 33-37.

3 Von Mersi W, Shinner F. An improved method and accurate method for determining the 4 dehydrogenase of soils with iodonitrotetrazolium chloride. Biol Fert Soils 1991; 11: 2165220.

6 Wentzel A, Ellingsen TE, Kotlar HK, Zotchev SB, Throne-Holst M. Bacterial metabolism of 7 long-chain n-alkanes. Appl Microbiol Biotechnol 2007; 76: 1209-1221. 


\section{Caption of figures}

2 Figure 1. Mean values and standard errors of a) total DNA, b) soil basal respiration, c)

3 dehydrogenase and d) catalase. Columns with the same letter do not differ significantly, $4 \quad P \leq 0.01$. Units are referred to dry weight of soil.

5

6 Figure 2. Mean values and standard errors of a) $\beta$-glucosidase, b) chitinase, c) protease and d)

7 acid-phosphatase. Columns with the same letter do not differ significantly, $P \leq 0.01$. Units are 8 referred to dry weight of soil.

9

10 Figure 3. Mean values and standard errors of simple microbiological ratios; a) total DNA/total

$11 \mathrm{~N}, \mathrm{~b}$ ) basal respiration/total DNA, c) dehydrogenase/total DNA and d) catalase/total DNA.

12 Columns with the same letter do not differ significantly, $\mathrm{P} \leq 0.01$. Units are referred to dry 13 weight of soil. 


\section{Figure}

Click here to download Figure: FiguresIl_210708.doc

Figure 1
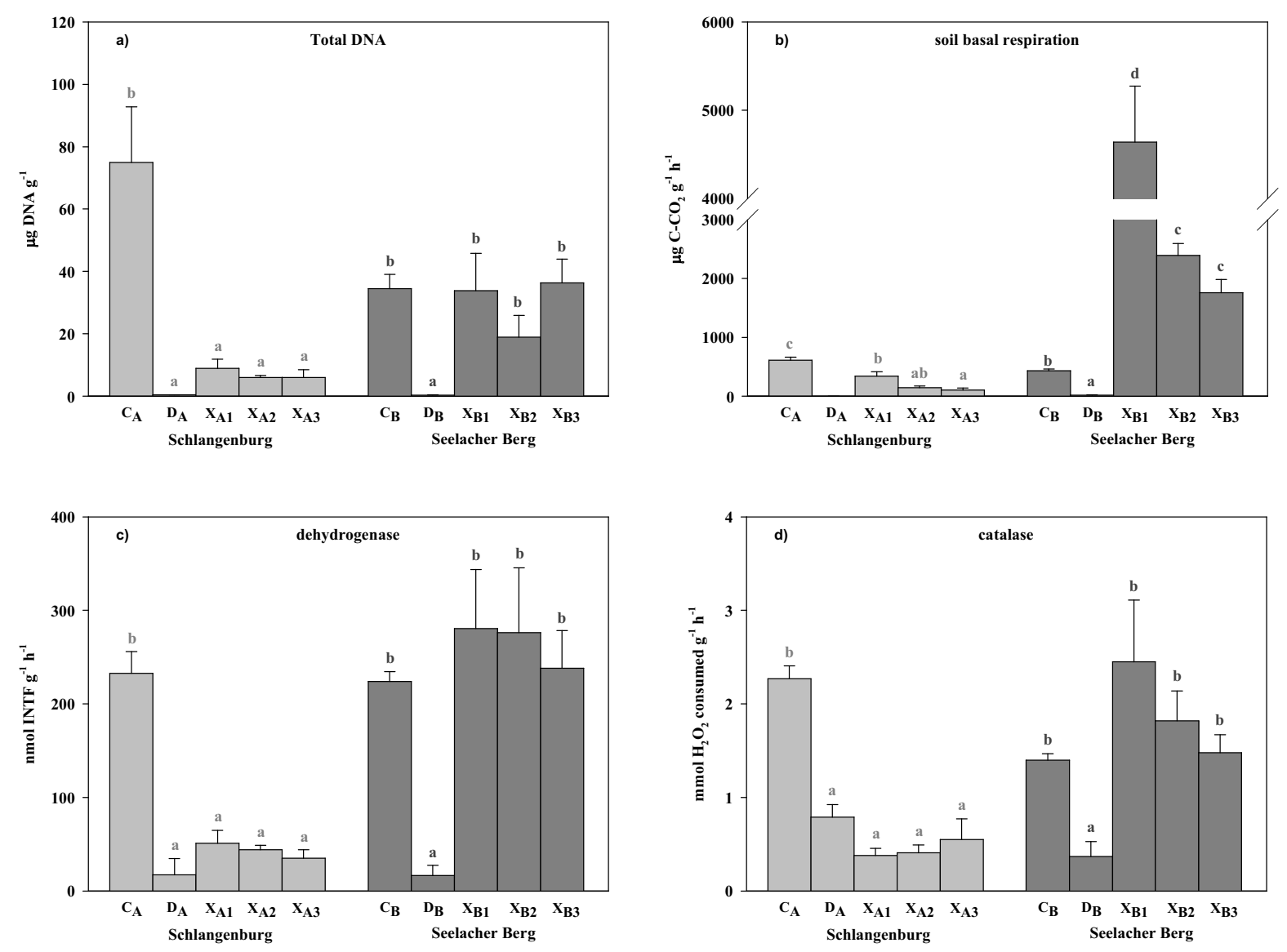
Figure 2
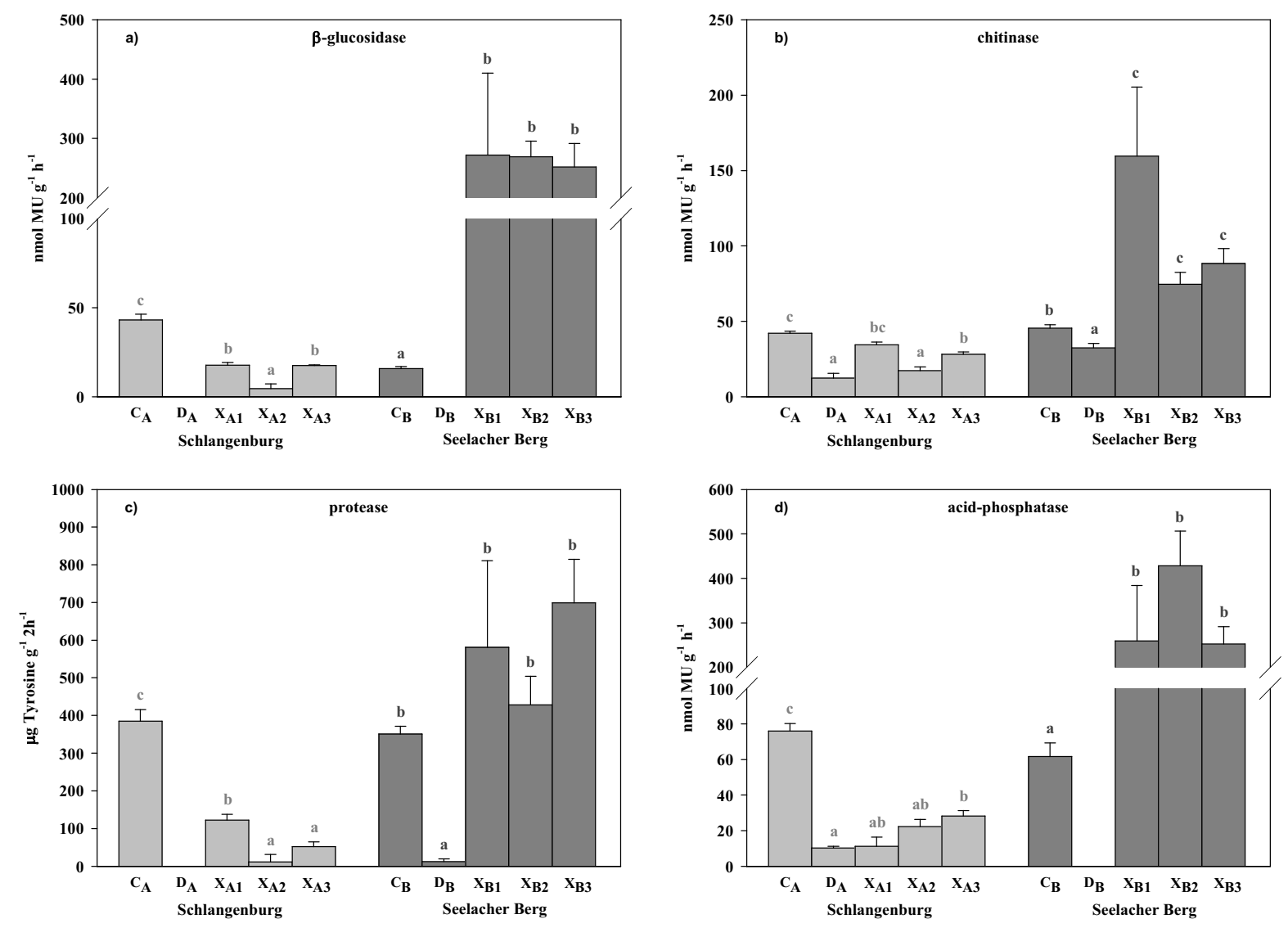
Figure 3
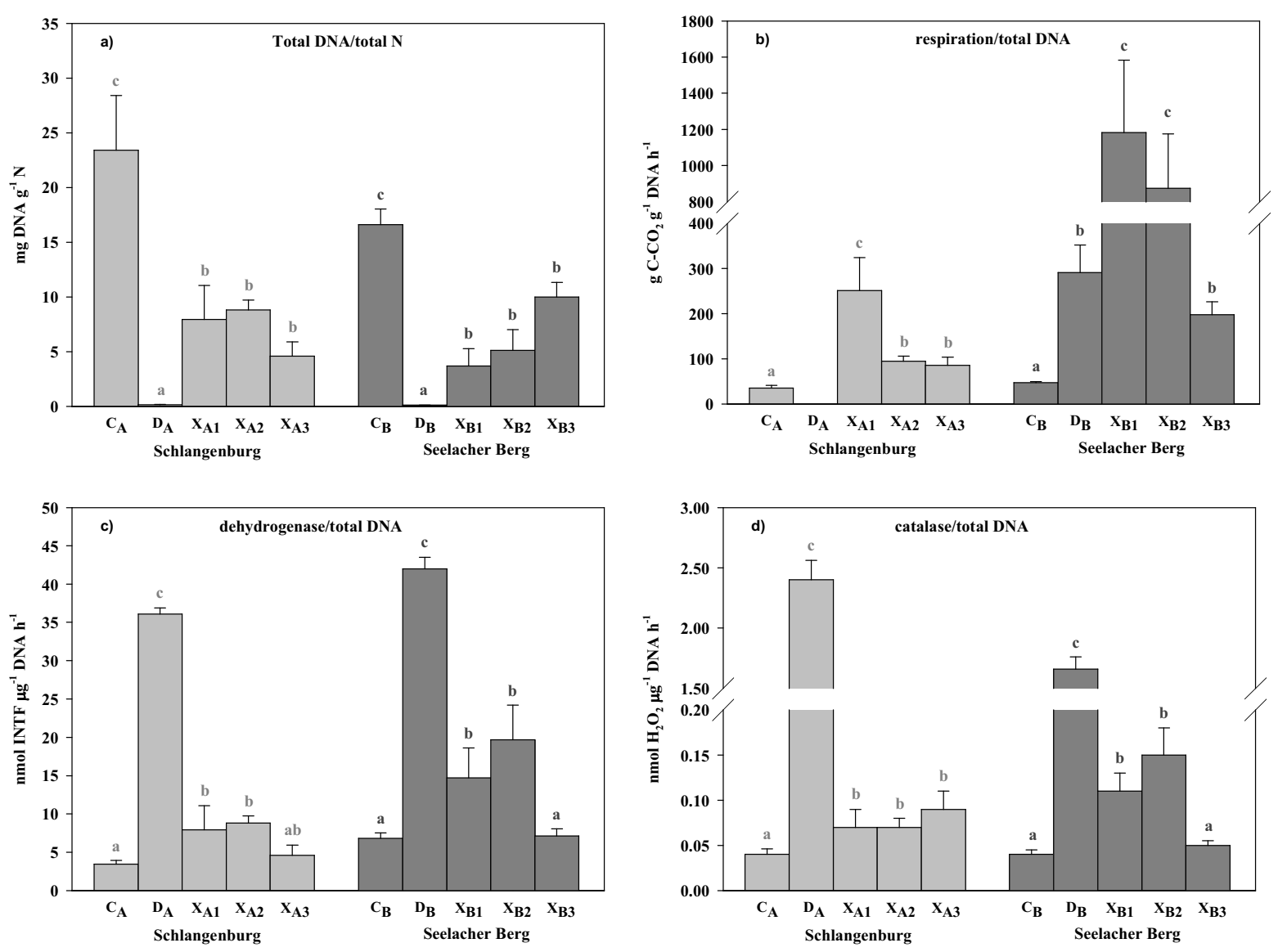
Table 1. Pearson's correlations between chemical and microbiological properties in site $A(N=20)$.

\begin{tabular}{|c|c|c|c|c|c|c|c|c|c|c|c|c|}
\hline & \multicolumn{12}{|c|}{ Site A (Schlangenburg) } \\
\hline & DNA & resp & deh & cat & $\beta$-glu & chit & prot & a-pho & $\begin{array}{l}\text { resp/ } \\
\text { DNA }\end{array}$ & $\begin{array}{l}\text { deh/ } \\
\text { DNA }\end{array}$ & $\begin{array}{l}\text { cat/ } \\
\text { DNA }\end{array}$ & $\begin{array}{l}\text { DNA/ } \\
\text { TN }\end{array}$ \\
\hline pH & -.035 & $-.537^{*}$ & -.093 & -.034 & -.234 & $-.562^{* *}$ & -.195 & .009 & $-.758^{* *}$ & -.272 & -.183 & .051 \\
\hline TOC & .406 & $.810^{* *}$ & $.550^{*}$ & $.593^{* *}$ & $.615^{*}$ & $.653^{*}$ & $.658^{* *}$ & .415 & .322 & -.160 & -.029 & .214 \\
\hline $\mathbf{T N}$ & $.690^{* *}$ & $.794^{* *}$ & $.807^{* *}$ & $.919^{* *}$ & $.879^{* *}$ & $.702^{* *}$ & $.867^{* *}$ & $.799^{* *}$ & -.177 & -.423 & -.175 & .419 \\
\hline Ex-C & .337 & $.776^{* *}$ & $.462^{*}$ & .428 & $.471^{*}$ & $.644^{* *}$ & .443 & .419 & $.657^{* *}$ & .314 & .209 & .173 \\
\hline $\mathbf{E x}-\mathbf{N}$ & $.483^{*}$ & $.849^{* *}$ & $.600^{* *}$ & $.538^{*}$ & $.629^{* *}$ & $.749^{* *}$ & $.576^{* *}$ & $.528^{*}$ & $.520^{*}$ & .178 & .060 & .305 \\
\hline Ex-P & $-.470^{*}$ & $-.606^{* *}$ & $-.570^{* *}$ & -.366 & $-.573^{* *}$ & $-.604^{* *}$ & $-.628^{* *}$ & $-.476^{*}$ & -.092 & -.044 & $.470^{*}$ & -.394 \\
\hline HC & -.308 & -.165 & -.275 & -.398 & $-.547^{*}$ & $-.552^{*}$ & -.329 & -.389 & .238 & .261 & -.021 & -.130 \\
\hline As & .037 & -.058 & .048 & .325 & .168 & -.013 & -.047 & .162 & -.286 & -.280 & .376 & -.088 \\
\hline Cd & -.223 & -.308 & -.244 & -.008 & -.105 & -.187 & -.374 & -.097 & -.094 & .016 & $.539^{*}$ & -.289 \\
\hline $\mathbf{C u}$ & -.313 & -.142 & -.282 & -.111 & .001 & .092 & -.318 & -.191 & .290 & .262 & $.696^{* *}$ & -.425 \\
\hline $\mathbf{P b}$ & -.158 & .313 & -.110 & -.181 & -.012 & .382 & .003 & -.325 & $.707^{* *}$ & .277 & .151 & -.131 \\
\hline $\mathbf{S}$ & -.237 & .290 & -.182 & -.201 & -.120 & .242 & -.140 & -.286 & $.894^{* *}$ & $.490^{*}$ & .428 & -.257 \\
\hline Zn & -.101 & .392 & .018 & .124 & .240 & $.490^{*}$ & .038 & .038 & $.704^{* *}$ & .427 & $.511^{*}$ & -.260 \\
\hline Ex-As & -.122 & -.184 & -.143 & -.112 & -.211 & -.202 & -.131 & -.035 & -.058 & -.018 & .118 & -.048 \\
\hline Ex-Cd & -.197 & .350 & -.101 & -.129 & -.058 & .244 & -.085 & -.072 & $.939^{* *}$ & $.647^{* *}$ & .440 & -.258 \\
\hline Ex-Cu & -.207 & .289 & -.146 & -.194 & -.101 & .248 & -.153 & -.161 & $.963^{* *}$ & $.687^{* *}$ & $.473^{*}$ & -.259 \\
\hline Ex-Pb & -.215 & .287 & -.198 & -.263 & -.079 & .310 & -.067 & -.323 & $.801^{* *}$ & .315 & .186 & -.213 \\
\hline Ex-S & -.208 & .302 & -.154 & -.198 & -.115 & .234 & -.143 & -.174 & $.958^{* *}$ & $.629^{* *}$ & $.456^{*}$ & -.254 \\
\hline Ex-Zn & -.166 & .384 & -.085 & -.110 & -.015 & .324 & -.052 & -.091 & $.939^{* *}$ & $.594^{* *}$ & .418 & -.235 \\
\hline
\end{tabular}

a-pho $=$ acid-phosphatase $; \beta$-gluc $=\beta$-glucosidase $;$ cat $=$ catalase $;$ chit $=$ chitinase $;$ deh $=$ dehydrogenase $; \mathrm{Ex}=$ extractable; $\mathrm{HC}=$ total hydrocarbons; pro = protease; resp = respiration; $\mathrm{TN}=$ total $\mathrm{N} ; \mathrm{TOC}=$ total organic $\mathrm{C}$.

$* P \leq 0.05 ; * * P \leq 0.01$. 
Table 2. Pearson's correlations between chemical and microbiological properties in site $B(\mathbf{N}=20)$.

\begin{tabular}{|c|c|c|c|c|c|c|c|c|c|c|c|c|}
\hline & \multicolumn{12}{|c|}{ Site B (Seelacher Berg) } \\
\hline & DNA & resp & deh & cat & $\beta$-glu & chit & prot & a-pho & $\begin{array}{l}\text { resp/ } \\
\text { DNA }\end{array}$ & $\begin{array}{l}\text { deh/ } \\
\text { DNA }\end{array}$ & $\begin{array}{l}\text { cat/ } \\
\text { DNA }\end{array}$ & $\begin{array}{l}\text { DNA/ } \\
\text { TN }\end{array}$ \\
\hline pH & $.468^{*}$ & .044 & $.486^{*}$ & .250 & $.577^{* *}$ & .221 & $.630^{* *}$ & $.606^{* *}$ & -.396 & -.373 & $-.449^{*}$ & .212 \\
\hline TOC & -.039 & $.796^{* *}$ & .026 & .205 & .148 & $.445^{*}$ & .058 & .031 & $.721^{* *}$ & .385 & .298 & $-.565^{* *}$ \\
\hline $\mathbf{T N}$ & .363 & $.950^{* *}$ & .408 & $.699^{* *}$ & $.619^{* *}$ & $.839^{* *}$ & $.461^{*}$ & .406 & .325 & .124 & .223 & $-.507^{* *}$ \\
\hline Ex-C & -.012 & -.147 & .112 & .212 & -.230 & -.126 & -.284 & -.128 & -.209 & -.067 & .082 & .149 \\
\hline $\mathbf{E x}-\mathbf{N}$ & .316 & -.101 & $.530^{*}$ & $.463^{*}$ & .148 & .052 & .101 & .268 & $.536^{*}$ & -.362 & -.208 & .386 \\
\hline Ex-P & .300 & $.466^{*}$ & $.513^{*}$ & $.568^{* *}$ & $.672^{* *}$ & $.552^{*}$ & $.488^{*}$ & $.588^{* *}$ & -.214 & -.145 & -.019 & -.300 \\
\hline HC & -.233 & $.530^{*}$ & -.173 & -.119 & -.150 & .105 & -.166 & -.166 & $.805^{* *}$ & $.456^{*}$ & .266 & $-.449^{*}$ \\
\hline As & .079 & $.865^{* *}$ & .130 & $.545^{*}$ & $.447^{*}$ & $.739^{* *}$ & .210 & .217 & .395 & .220 & .396 & $-.625^{* *}$ \\
\hline Cd & .173 & $.734^{* *}$ & .266 & $.635^{* *}$ & $.764^{* *}$ & $.756^{* *}$ & .441 & $.633^{* *}$ & .231 & .297 & $.529^{*}$ & $-.593^{* *}$ \\
\hline $\mathrm{Cu}$ & -.142 & $.678^{* *}$ & -.103 & .047 & .023 & .293 & -.038 & -.041 & $.813^{* *}$ & $.479^{*}$ & .345 & $-.531^{*}$ \\
\hline $\mathbf{P b}$ & -.188 & $.588^{* *}$ & -.146 & -.060 & -.087 & .173 & -.108 & -.119 & $.821^{* *}$ & $.477^{*}$ & .296 & $-.470^{*}$ \\
\hline $\mathbf{S}$ & -.132 & $.749^{* *}$ & -.070 & .134 & .068 & .378 & -.034 & -.041 & $.767^{* *}$ & .440 & .360 & $-.583^{* *}$ \\
\hline Zn & .379 & $.718^{* *}$ & .334 & $.704^{* *}$ & $.757^{* *}$ & $.835^{* *}$ & $.563^{* *}$ & $.585^{* *}$ & .140 & .143 & .338 & -.320 \\
\hline Ex-As & -.199 & .440 & -.078 & .245 & .000 & .290 & -.233 & -.156 & .189 & .068 & .290 & -.423 \\
\hline Ex-Cd & $-.446^{*}$ & $.486^{*}$ & -.275 & .108 & .003 & .200 & -.359 & -.114 & $.543^{*}$ & $.530^{*}$ & $.747^{* *}$ & $-.743^{* *}$ \\
\hline $\mathbf{E x}-\mathbf{C u}$ & -.207 & .305 & -.096 & .203 & -.044 & .139 & -.255 & -.160 & .186 & .126 & .317 & -.388 \\
\hline Ex-Pb & -.294 & .443 & -.133 & .096 & -.185 & .146 & -.344 & -.298 & .433 & .257 & .318 & $-.498^{*}$ \\
\hline Ex-S & -.337 & $.560^{*}$ & -.169 & .184 & .030 & .285 & -.267 & -.102 & $.519^{*}$ & $.463^{*}$ & $.622^{* *}$ & $-.678^{* *}$ \\
\hline Ex-Zn & -.374 & $.560^{*}$ & -.229 & .173 & -.102 & .308 & -.260 & -.037 & $.529^{*}$ & $.529^{*}$ & $.734^{* *}$ & $-.737^{* *}$ \\
\hline
\end{tabular}

a-pho = acid-phosphatase $\beta$-gluc $=\beta$-glucosidase $;$ cat $=$ catalase $;$ chit $=$ chitinase $;$ deh $=$ dehydrogenase $; \mathrm{Ex}=$ extractable; $\mathrm{HC}=$ total hydrocarbons; pro = protease; resp $=$ respiration; $\mathrm{TN}=$ total $\mathrm{N} ; \mathrm{TOC}=$ total organic $\mathrm{C}$.

$* P \leq 0.05 ; * * P \leq 0.01$. 